\title{
Exploring the Nutritive Values of the Fresh Water Mussel Lamellidens marginalis as Potential Functional Food
}

\author{
Ankhi Haldar ${ }^{1}$, Tanmoy Kumar Dey ${ }^{1}$, Pubali Dhar ${ }^{1}$ and Jana Chakrabarti ${ }^{2 *}$ \\ ${ }^{1}$ Laboratory of Food Science, Food \& Nutrition Division, University of Calcutta, 20 B Judges Court Road \\ Kolkata-700027, West Bengal \\ ${ }^{2}$ Department of Biotechnology, Presidency University, (Erstwhile Presidency College), 86/1, College Street, \\ Kolkata-700073, West Bengal
}

\begin{abstract}
Prevention of under-nutrition has emerged as a critical challenge to India's development planners in recent times. Insufficient protein consumption results in Protein Energy Malnutrition among the children in our Country. Due to increasing cost, limited amount of animal protein and the limited potential for improving the situation through increased animal production, the need of the hour is to search for an efficient utilization of cheap and available unconventional animal protein resources. Molluscs are regarded as under-exploited source of health-benefit molecules. Present investigation attempts to evaluate the nutritive values of the fresh water bivalve Lamellidens marginalis, widely accepted as food all over India. Proximate analyses revealed that mussel meat contains moderate amount of protein $(8.30 \pm 0.67 \%)$, carbohydrate $(8.01 \pm 0.38 \%)$ and reducing sugar $(4.75 \pm 0.07 \%)$, but less amount of fat (1.02 $\pm 0.20 \%)$ and crude fibre $(0.01 \pm .001 \%)$. Lipid constitutes substantial amount of omega-3-fatty acids like, eicosapentaenoic acid (EPA), docosahexaenoic acid (DHA) which have proven prophylactic values. Protein analysis shows the presence of several essential amino acids required for proper body growth and maintenance. Moreover, antioxidant activity of the haemolymph further established that this benthic mussel can serve as an excellent alternate food source and can thus be commercialized as low cost functional food.
\end{abstract}

Keywords: Bivalves, Functional Food, Lamellidens marginalis, Nutrition, Proximate analysis.

\section{Introduction}

High incidences of Protein Energy Malnutrition as a consequence of low protein intake are quite prevalent among the children in developing and under developed economies [1]. Increase in population over the decades has lead to greater pressure on the existing animal protein sources. Poultry, pork, beef, lamb and fish are considered as the major sources of meat protein for humans. But these sources are currently declining due to persistent drought, diseases, natural disasters, high cost of feed, and low productivity of local breeds and this decline in productivity is most evident in some developing countries [2].The role of livestock and fisheries sectors to fulfil the growing demand for food is of paramount importance for nutritional security. So the need of the hour is to search for unconventional low cost animal protein resources. Among the unconventional sources of animal proteins, molluscs as a group have good prospects [3]. Bivalves are the second largest Class of Phylum Mollusca. Annual harvests of bivalves for human consumption represent about $5 \%$ by weight of the total world harvest of aquatic resources [4]. The freshwater mussel Lamellidens marginalis is widely distributed in ponds and large bodies of perennial waters in the Indian sub-continent [5] and well accepted as food all over India [6] .Present investigation attempts to evaluate the nutritive values and the potential of the edible fresh water bivalve Lamellidens marginalis as a functional food.

\subsection{Sample Collection}

\section{Materials And Methods}

The benthic bivalve Lamellidens marginalis were collected from the fresh water ponds in West Bengal. Identification of the species was done from the Zoological Survey of India, Kolkata. Specimens were brought to the laboratory two days before experimentation. Bivalves of similar size $(8 \mathrm{~cm}-10 \mathrm{~cm}$ long) and average weight (55-70 gm with shell) were cleaned by thorough washing with water to remove fouling biomass and algal biomass and allowed to acclimatize in laboratory conditions in a 50 litre glass aquarium. Haemolymph was collected from individual specimen by gently prying the shell to open approximately 5 to $7 \mathrm{~mm}$ with a thin knife. The shell was held open with tissue forceps. White muscular foot was gently penetrated with a 26 Gauge $\left(\mathrm{G}^{1} / 2\right)$ $(0.45 \mathrm{~mm} \times 13 \mathrm{~mm})$ sized needle to collect haemolymph using gentle intermittent suction [7]. Finally, shells were removed carefully to separate the edible muscle mass. Shell and Flesh both were preserved at $-20^{\circ} \mathrm{C}$ until analysis. 


\subsection{Nutrient Analysis}

Moisture, ash and fibre contents of the tissue homogenate were determined by the method of the Association of Official Analytical Chemists [8]. Total protein was determined by the Micro-Kjeldahl method [9]. Carbohydrate was determined by AOAC method [8]. The amount of reducing sugar present in tissue homogenate was analyzed by Nelson-Somogyi methods [10]. Tissue Lipid was determined by the method of Bligh and Dyer [11] with slight modification by Floch et.al [12]. Phospholipids [13], Cholesterol [14] and Triacylglycerol [15] were assayed by standard AOCS methods.

\subsection{Fatty Acid Analysis}

The extracted tissue lipid was stored at $-20^{\circ} \mathrm{C}$ before analysis. The lipid samples were first converted to their constituent fatty acid methyl esters (FAMEs). Approximately $25 \mathrm{mg}( \pm 0.1 \mathrm{mg}$ ) of oil was weighed and added with $1.5 \mathrm{ml}$ of $0.50 \mathrm{M} \mathrm{NaOH}$ in methanol in a $15 \mathrm{ml}$ capped centrifuge tube. The mixture was heated in a water bath at $100^{\circ} \mathrm{C}$ for $5 \mathrm{~min}$ and then cooled at room temperature. The mixture was then added with $2.0 \mathrm{ml}$ of boron trifluoride $\left(\mathrm{BF}_{3}, 12 \%\right)$ in methanol and heated again in a water bath at $100^{\circ} \mathrm{C}$ for 30 minutes. Next, the tube was cooled in running water at room temperature before adding $1 \mathrm{ml}$ of isooctane. It was vigorously stirred for 30 seconds before adding $5.0 \mathrm{ml}$ of a saturated sodium chloride solution to facilitate the phase separation. The esterified sample was kept in the refrigerator and left for better phase separation. After collecting the supernatant, another $1.0 \mathrm{ml}$ of isooctane (containing $0.05 \%$ BHT as antioxidant) was added into the tube and stirred. The supernatant was collected and added to the previous fraction. The sample was concentrated to a final volume of $1.0 \mathrm{ml}$ for later injection into the gas chromatograph. As precautions, amber vials were used in order to minimize oxidation during analysis. FAMEs were separated by gas chromatograph (HP $6890 \mathrm{~N}$, Agilent Technologies, USA) [16].

\subsection{Amino Acid Analysis}

Oven dried powdered samples were extracted and hydrolysed in $6 \mathrm{~N} \mathrm{HCL}$ at $110^{\circ} \mathrm{C}$ for 24 hours and the amino acids were estimated through HPLC (Merk-Hitachi-7400) following the method of Baker and Han [17].

\subsection{Estimation of Vitamins}

Fat soluble vitamin A was analysed through HPLC (Merk-Hitachi-7400) by the method described by Sadasivam and Manickam [18] and water soluble vitamin C was estimated by the method of Omaye et.al. [19].

\subsection{Estimation of Minerals and Heavy Metals}

Both the flesh and the shell were taken for the quantitative estimation of minerals. The minced flesh and shell $\left(2 \mathrm{gm}\right.$ each) were oven dried at $105^{\circ} \mathrm{C}$ for 2 hours for grinding and then $1 \mathrm{gm}$ of each was heated at $550^{\circ} \mathrm{C}$ in a muffle furnace for 6 hours. The ashes of flesh and shell were then dissolved in concentrated HCl. $2 \mathrm{~N}$ $\mathrm{HNO}_{3}$ was then added to boil the ash solutions separately. Solutions were then filtered through Whatman No. 40 filter paper and volumes were made up to $50 \mathrm{ml}$ with double distilled water. The instrument ICP (OES), model ICAP6800, serial number ICP 20073108 was calibrated with NIST certified multi-standards. Fe, Ca, Mg, Mn, $\mathrm{Zn}, \mathrm{Se}, \mathrm{P}, \mathrm{Na}, \mathrm{K}, \mathrm{Pb}, \mathrm{Cd}, \mathrm{Ni}, \mathrm{Cu}, \mathrm{Cr}$ were estimated by the following methods reported by Association of Official Analytical Chemists [8].

\section{7 in vitro Antioxidant Activity}

The haemolymph was filter sterilized to remove the cells and analyzed for antioxidant activity.

\subsubsection{FRAP (Ferric reducing antioxidant power) Assay}

The FRAP (Ferric Reducing Antioxidant Power) assay was estimated by the method of Benzie et.al [20]. FRAP reagents contain $5 \mathrm{ml}$ of $(10 \mathrm{mmol} / \mathrm{L})$ TPTZ (2, 4, 6-tripyridyl-S-triazine) solution in 40 $\mathrm{mmol} / \mathrm{L}$ HCL plus $5 \mathrm{ml} \mathrm{of} \mathrm{FeCl}_{3}(20 \mathrm{mmol} / \mathrm{L})$ and $50 \mathrm{ml}$ of acetate buffer, $(0.3 \mathrm{~mol} / \mathrm{L}, \mathrm{pH}=3.6)$. Standard was prepared by adding $\mathrm{FeSO}_{4}, 7 \mathrm{H}_{2} \mathrm{O}$ in methanol and five concentrations were taken from 100 to $500 \mu \mathrm{M}$. $50 \mu \mathrm{l}$ and $100 \mu \mathrm{l}$ of haemolymph were taken and incubated at $37^{\circ} \mathrm{C}$ for 4 mins. After 4 minutes the reading was measured at $593 \mathrm{~nm}$ wavelength.

\subsubsection{Hydroxyl radical scavenging activity}

The Hydroxyl radical scavenging activity was determined according to the method described by Singh, Murthy and Jayprakash [21]. Different volumes $(10 \mu 1,25 \mu 1,50 \mu 1$,) of the haemolymph were taken. $1 \mathrm{ml}$ of ironEDTA solution $(0.1 \%$ Ferrous ammonium sulphate and $0.26 \%$ EDTA), $0.5 \mathrm{ml}$ of EDTA solution $(0.018 \%)$, and $1 \mathrm{ml}$ of DMSO $(0.85 \% \mathrm{v} / \mathrm{v}$ in $0.1 \mathrm{M}$ phosphate buffer, $\mathrm{pH} 7.4)$ were added and the reaction was initiated by adding $0.5 \mathrm{ml}$ of $0.22 \%$ ascorbic acid. Test tubes were heated on a water bath at $80^{\circ}-90^{\circ} \mathrm{C}$ for $15 \mathrm{~min}$. The reaction was terminated by the addition of $1 \mathrm{ml}$ ice cold trichloroacetic acid (TCA) $(17.5 \% \mathrm{w} / \mathrm{v}) .3 \mathrm{ml}$ Nash 
reagent was added and left at room temperature for $15 \mathrm{~min}$ for colour development. The intensity was measured at $412 \mathrm{~nm}$ wavelength. The percentage of hydroxyl radical scavenging activity is calculated by the following formula:

$\%$ hydroxyl radical scavenging activity $=1-\frac{\text { Absorbance of the sample }}{\text { Absorbance of the blank }} \times 100$

\section{Statistical Analysis}

Results are expressed as Mean \pm SE. Data were analysed using Statistical Product and Service Solutions Software (SPSS student version 7.5).

\subsection{Proximate Composition}

\section{Results And Discussion}

Table 1 represents the proximate nutrient composition of the flesh of Lamellidens marginalis. In the present investigation the recorded moisture content of the sample is $80.03 \%$. The ash content of the sample is $2.63 \%$. The proximate nutrient analyses of the flesh of this freshwater bivalve reveal that it contains less fat, moderate amount of protein, carbohydrate and reducing sugar. In this investigation, we have demonstrated that mussel meat contains moderate amount of protein $(8.30 \pm 0.67 \%)$, carbohydrate $(8.01 \pm 0.38 \%)$ and reducing sugar $(4.75 \pm 0.07 \%)$, but less amount of fat $(1.02 \pm 0.20 \%)$. The proximate compositions are comparable with other studies with slight difference in carbohydrate and fat content. These differences may be due to differences in environment and the nature of the diet of the organism.

Table 1: Proximate composition of the flesh of Lamellidens marginalis in percentage ( $\mathrm{g} \%$ of dry wt.)

\begin{tabular}{|c|c|c|c|c|c|c|}
\hline $\begin{array}{c}\text { Moisture } \\
\text { Mean } \pm \text { S.E }\end{array}$ & $\begin{array}{c}\text { Ash } \\
\text { Mean } \pm \text { S.E }\end{array}$ & $\begin{array}{c}\text { Protein } \\
\text { Mean } \pm \text { S.E }\end{array}$ & $\begin{array}{c}\text { Fat } \\
\text { Mean } \pm \text { S.E }\end{array}$ & $\begin{array}{c}\text { Carbohydrate } \\
\text { Mean } \pm \text { S.E }\end{array}$ & $\begin{array}{c}\text { Reducing } \\
\text { Sugar } \\
\text { Mean } \pm \text { S.E }\end{array}$ & $\begin{array}{c}\text { Crude Fibre } \\
\text { Mean } \pm \text { S.E }\end{array}$ \\
\hline $80.03 \pm 0.09$ & $2.63 \pm 0.11$ & $8.30 \pm 0.67$ & $1.02 \pm 0.20$ & $8.01 \pm 0.38$ & $4.75 \pm 0.07$ & $0.01 \pm 0.001$ \\
\hline
\end{tabular}

\subsection{Lipid Composition}

Table 2 represents percentage of different categories of lipid present in the flesh of Lamellidens. It shows less cholesterol and triacylglycerol but significantly high amount of phospholipids. Table 3 and Fig. 1 represent the fatty acid composition of the flesh of Lamellidens. Among saturated fatty acids (SFAs), arachidic acid (C20:0) is dominant, followed by palmitic acid (C16:0), behenic acid (C22:0), stearic acid (C18:0), lignoceric (C24:0) amounting 18.90\%, 14.33\%, 7.55\%, 6.61\%, 2.04\% respectively of the total fatty acids. The main monounsaturated fatty acid is palmitoleic acid (C16:1) amounting $22.18 \%$ of the total fatty acids. The dominant PUFA is $\alpha$-linolenic acid amounting $14.17 \%$, followed by docosahexaenoic acid (DHA), eicosapentaenoic acid (EPA) and arachidonic acid (C20:4) amounting 9.55\%, 3.43\%, 1.53\% respectively of total fatty acids. Recent studies reveal that high dietary PUFA when SFA intake remains the same may enhance platelet aggregation. On the other hand, it is now established that substitution of SFA by MUFA lowers both total and LDL cholesterol [22]. Experimental studies suggest that Omega-3 fatty acids, such as docosahexaenoic acid (DHA) and eicosapentaenoic acid (EPA) are more important for enzymatic pathways linked to long chain polyunsaturated fatty acid metabolism [23].

Table 2: Fat content in the flesh of Lamellidens marginalis (\%)

\begin{tabular}{|c|c|}
\hline Type & $\begin{array}{c}\text { Content (\%) } \\
\text { Mean } \pm \text { S.E }\end{array}$ \\
\hline Phospholipids & $19.43 \pm 1.18$ \\
\hline Triacylglycerol & $70.67 \pm 6.001$ \\
\hline Cholesterol & $9.90 \pm 1.56$ \\
\hline
\end{tabular}

Table 3: Fatty Acid composition of the flesh of Lamellidens marginalis (\%)

\begin{tabular}{|c|c|c|}
\hline Type & Name & $\begin{array}{c}\text { Unit (\%) } \\
\text { Mean } \pm \text { S.E }\end{array}$ \\
\hline Saturated Fatty Acid & Palmitic Acid & $14.33 \pm 0.05$ \\
i)C16:0 & Stearic Acid & $6.61 \pm 0.20$ \\
ii)C18:0 & Arachidic Acid & $18.90 \pm 0.03$ \\
iii)C20:0 & Behenic Acid & $2.55 \pm 0.23$ \\
v)C24:0 & Lignoceric Acid & $2.04 \pm 0.11$ \\
\hline Monounsaturated Fatty Acid & Palmitoleic Acid & $22.18 \pm 0.44$ \\
i)C16:1 & www.iosrjournals.org & $22.18 \pm 0.02$ \\
\hline
\end{tabular}




\begin{tabular}{|c|c|c|}
\hline Polyunsaturated Fatty Acid & & $28.62 \pm 0.03$ \\
i)C18:3 & $\alpha$ Linolenic Acid & $14.14 \pm 0.02$ \\
ii)C20:4 & Arachidonic Acid & $1.50 \pm 0.02$ \\
iii)C20:5 & Eicosapentaenoic Acid & $3.43 \pm 0.07$ \\
iv)C22:6 & Docosahexaenoic acid & $9.55 \pm 0.06$ \\
\hline
\end{tabular}

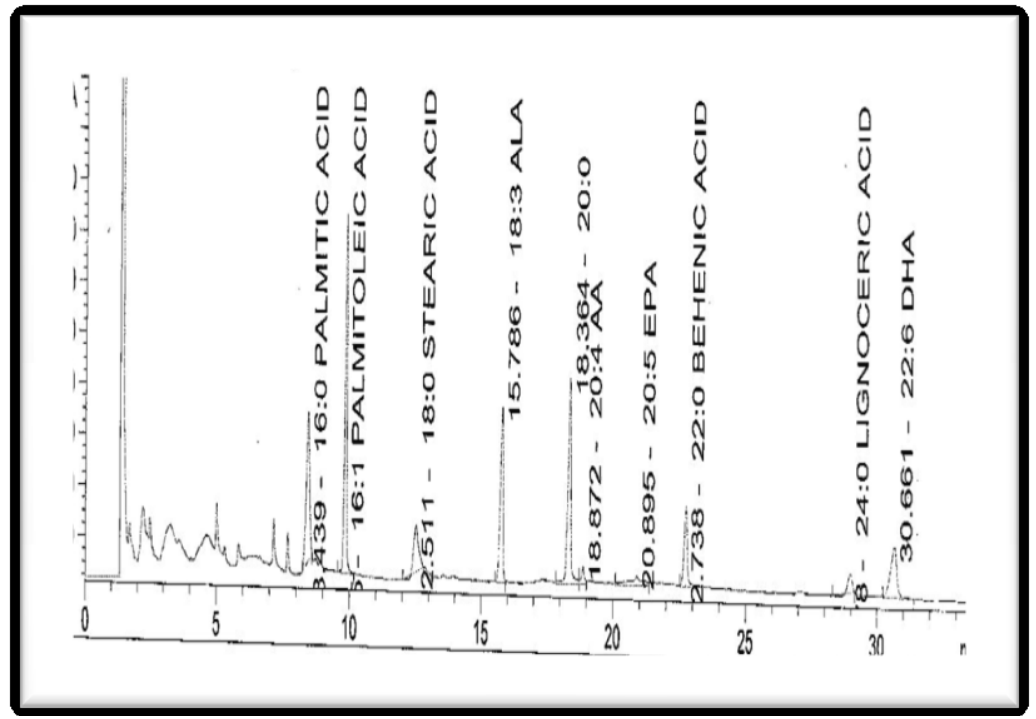

Figure1: Fatty Acids composition of the flesh of Lamellidens marginalis

\subsection{Amino Acid Composition}

Amino Acid composition of the flesh of this edible mussel is shown in Table 4. It reveals that mussel meat has a considerable quality and quantity of amino acids in its composition. Among the Essential Amino Acids (EAA), Arginine, Valine, Lysine, Isoleucine, Leucine, Tryptophan are found most prominent. They are necessary for various physiological functions. Arginine plays important role in cell division, healing of wounds, removing ammonia from the body and immune function. Valine is necessary for muscle metabolism and for the repairing of tissues. Lysine helps in the synthesis of carnitine, lowering of cholesterol and the formation of antibodies, hormones and connective tissues. Leucine increases muscle mass and promotes bio-synthesis of sterols in the body and has the ability to stimulate muscle growth and inhibit muscular degradation. Isoleucine builds proteins and enzymes, stimulates the brain, promotes muscle recovery after physical exercise, regulates blood sugar levels and is used to make the vital iron carrying haemoglobin. Tryptophan assists normal growth in infants and for nitrogen balance in adults. Body uses tryptophan to make vitamin B, niacin, and the neurotransmitter, serotonin. Among the non-essential amino acid, glutamic acid is dominant followed by aspartic acid, proline, glycine, serine, alanine, tyrosine of total amino acid contents. Aspartic acid acts as a neurotransmitter and is involved in hormone production and nervous system function. Glutamic Acid helps to prevent ammonia intoxication, and is an active neurotransmitter substance which is important for memory and learning. Serine plays a major role as a catalyst for many enzyme functions, synthesizes fatty-acid based sheaths around the nerve fibers. It is involved in the formation of immunoglobulins and thus helps in strengthening body's immune system. Tyrosine is a building block for several neurotransmitters and can regulate hormonal activities in the body [22].

Table 4: Amino acid composition of the flesh of Lamellidens marginalis

\begin{tabular}{|c|c|}
\hline Amino Acid & $\begin{array}{c}\text { Content (mg/100gm Dry weight) } \\
\text { Mean } \pm \text { S.E }\end{array}$ \\
\hline Histidine & $180 \pm 1.63$ \\
\hline Arginine & $940 \pm 2.45$ \\
\hline Threonine & $250 \pm 1.64$ \\
\hline Valine & $270 \pm 2.47$ \\
\hline Methionine & $130 \pm 2.44$ \\
\hline Lysine & $360 \pm 1.65$ \\
\hline Isoleucine & $240 \pm 2.45$ \\
\hline Leucine & $440 \pm 1.64$ \\
\hline Phenylalanine & $230 \pm 2.45$ \\
\hline Tryptophan & $120 \pm 2.44$ \\
\hline Aspartic Acid & $560 \pm 2.31$ \\
\hline Serine & $300 \pm 2.89$ \\
\hline
\end{tabular}


Exploring the Nutritive Values of the Fresh Water Mussel Lamellidens marginalis as Potential.....

\begin{tabular}{|c|c|}
\hline Glutamic Acid & $840 \pm 2.32$ \\
\hline Glysine & $330 \pm 3.47$ \\
\hline Cystine & Below Detection Range \\
\hline Tyrosine & $150 \pm 3.46$ \\
\hline
\end{tabular}

\subsection{Vitamin Content}

Vitamin content of flesh of this molluscan species is presented in Table 5. Vitamin A and C are found present in considerable amount. Vitamin A is important for new cell growth, healthy skin and tissues and vision in dim light. Vitamin $\mathrm{C}$ is the most important water-soluble antioxidant in extracellular fluid and it helps to neutralize reactive oxygen species (ROS) in the water or aqueous phase before it can attack the lipids. For the immune system to function properly, vitamin $\mathrm{C}$ is a must because it is involved with $\mathrm{T}$-cells and white blood cells [22].

Table 5: Vitamin content of the flesh of Lamellidens marginalis
\begin{tabular}{|c|c|}
\hline Parameter & $\begin{array}{c}\text { Content } / \mathbf{1 0 0 g m} \\
\text { Mean } \pm \text { S.E }\end{array}$ \\
\hline Vitamin A & $87.60 \pm 0.89 \mu \mathrm{g}$ \\
\hline Vitamin C & $22.00 \pm 0.88 \mathrm{mg}$ \\
\hline
\end{tabular}

\subsection{Mineral composition}

Mineral composition of both the flesh and the shell are presented in Table 6. The analysis of the minerals in Lamellidens marginalis shows that it is a good source of minerals both quantitatively and qualitatively. It contains good amounts of calcium, phosphorus, iron, sodium, potassium, magnesium, manganese, zinc and also selenium. Biochemical constituents and minerals assist to supply energy required for the body to carry out physiological functions. High concentration of calcium in mussel meat may help to increase the calcium level in the body and can contribute tremendously in several important cellular processes. On the other hand, half of the iron in meat is present as heam iron (in haemoglobin) [24]. This is well absorbed with about $15 \% \sim 35 \%$, a figure that can be contrasted with other forms of iron, such as that from plant foods, at $1 \% \sim 10 \%$. The iron from meat does not only enhance the absorption of iron from other sources such as cereal but increases considerably the level of iron absorption in the blood and prevents anaemia. Good amount of phosphorus also can assist in the formation of bones and teeth. Sodium and potassium are needed to control osmotic pressure and water balance of the body as they are the principal electrolytes of our body. Magnesium helps in muscle contraction and relaxation, production and transport of energy and also involves in production of protein. Manganese is a component of the anti-oxidant enzyme superoxide dismutase (SOD), which helps to fight against free radicals that occur naturally in the body and can damage cell membranes and DNA. Zinc is a micro nutrient required in small quantities, but is an important component of more than 300 enzymes and participates in the metabolism of other micronutrient. Selenium, On the other hand, functions as co-factor for glutathione peroxidase and it is also essential for thyroid functioning along with iodine. The antioxidant enzymes like glutathione peroxidase, catalase, and superoxide dismutase (SOD) help to protect cells from ROS mediated damage. They require micronutrient co-factors such as selenium, iron, copper, zinc, and manganese for their activity. Thus inadequate dietary intake of these trace minerals may lead to low antioxidant activity.

Table 6: Mineral content in the flesh and the shell of Lamellidens marginalis

\begin{tabular}{|c|c|c|}
\hline Mineral & $\begin{array}{c}\text { Content in Flesh } \\
\text { (mg /100 gm of dry wt.) } \\
\text { Mean } \pm \text { S.E }\end{array}$ & $\begin{array}{c}\text { Content in Shell } \\
\text { (mg / /100 gm of dry wt. }) \\
\text { Mean } \pm \text { S.E }\end{array}$ \\
\hline Calcium & $256.9 \pm 1.12$ & $3706 \pm 1.26$ \\
\hline Iron & $361.2 \pm 0.97$ & $19.13 \pm 0.33$ \\
\hline Phosphorus & $746.5 \pm 0.92$ & $14.57 \pm 0.61$ \\
\hline Sodium & $66.4 \pm 0.60$ & $115.5 \pm 0.64$ \\
\hline Potassium & $103.38 \pm 0.45$ & $153.4 \pm 0.89$ \\
\hline Magnesium & $23.25 \pm 0.88$ & $118.60 \pm 0.62$ \\
\hline Manganese & $67.26 \pm 0.64$ & $113.8 \pm 0.65$ \\
\hline Zinc & $43.8 \pm 0.79$ & $0.63 \pm .009$ \\
\hline Selenium & $0.63 \pm .008$ & $0.13 \pm .008$ \\
\hline Total Mineral Contents & $1.67 \%$ & $4.24 \%$ \\
\hline
\end{tabular}

Table 7 represents amount of heavy metals present both in the shell and the flesh of Lamellidens marginalis. 
Table 7: Heavy metal content in the flesh and the shell of Lamellidens marginalis

\begin{tabular}{|c|c|c|}
\hline Heavy Metals & $\begin{array}{c}\text { Content in Flesh }(\mathbf{p p m}) \\
\text { Mean } \pm \text { S.E }\end{array}$ & $\begin{array}{c}\text { Content in Shell (ppm) } \\
\text { Mean } \pm \text { S.E }\end{array}$ \\
\hline Nickel & $1.11 \pm 0.01$ & $9.85 \pm 0.68$ \\
\hline Copper & $3.23 \pm 0.13$ & $2.38 \pm 0.11$ \\
\hline Cadmium & $0.39 \pm .002$ & $2.98 \pm 0.12$ \\
\hline Arsenic & $<0.2$ & $<0.2$ \\
\hline Lead & $5.98 \pm 0.07$ & $37.56 \pm 0.02$ \\
\hline Chromium & $1.58 \pm 0.02$ & $0.1 \pm 0.002$ \\
\hline
\end{tabular}

\subsection{Antioxidant Activity}

Oxidative stress can be generated due to several environmental factors such as exposure to pollutants, infections, poor diet, toxins, radiation etc. [25]. Thus to study its potential as functional food, apart from the nutritive value, primary investigations have been made on the antioxidant activity of haemolymph of Lamellidens (Fig.2 \& Fig.3). In our investigation a progressive anti-oxidative effect has been demonstrated which suggests that it may prevent cells from oxidative stress and generation of reactive oxygen species (ROS).

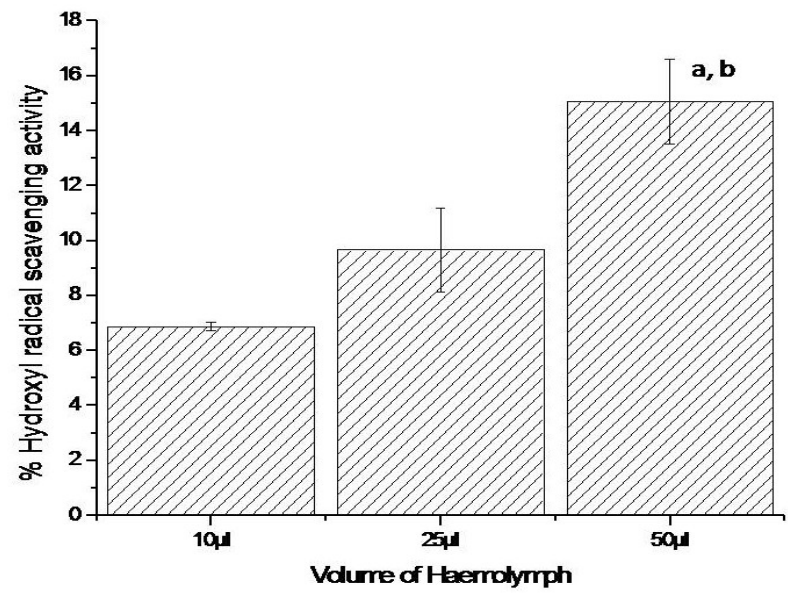

Figure 2: Hydroxyl radical scavenging activity (expressed as \%) of different volume (10 $\mu \mathrm{l}, 25 \mu \mathrm{l}, 50 \mu \mathrm{l})$ of the haemolymph, collected from Lamellidens marginalis. All values are expressed as mean \pm standard deviation for triplicate experiments. All the superscripts here are indicative of statistically significant differences between the activity of different volumes of haemolymph, at significance level of $0.01, a=10 \mu \mathrm{l}$ vs. $50 \mu \mathrm{l}$ of haemolymph; $b=25 \mu l$ vs. $50 \mu \mathrm{l}$ of haemolymph.

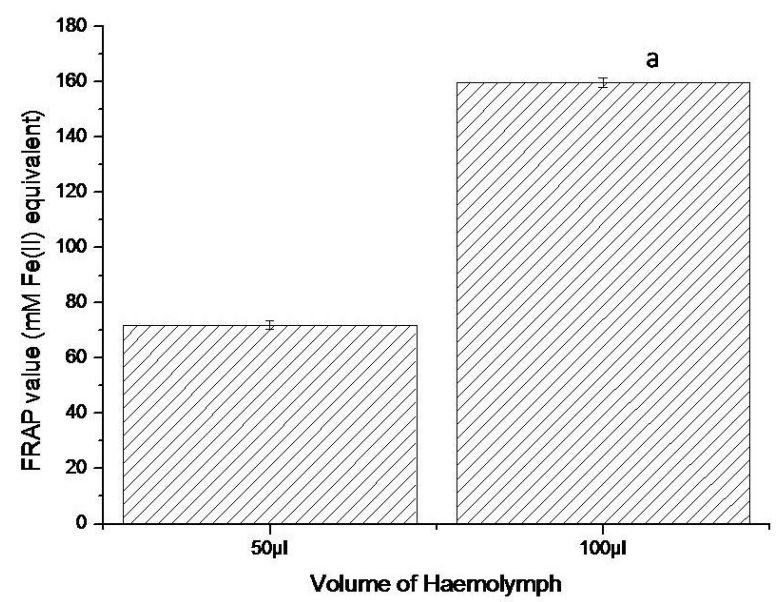

Figure 3: Ferric reducing antioxidant power (FRAP) [expressed as $\mathrm{mM}$ Fe (II) equivalent] of the haemolymph, collected from Lamellidens marginalis. All values are expressed as mean \pm standard deviation for triplicate experiments. The superscript here is indicative of statistically significant differences between the activity of different volumes of haemolymph, at significance level of $0.01, a=50 \mu \mathrm{l}$ vs. $100 \mu$ l of haemolymph. 


\section{Conclusion}

Taken together the present observations made in this study propose that the freshwater mussel Lamellidens marginalis can be considered as a supplementary food source for both old and young, because this will combine effectively with other food components for providing required essential elements to the body. But the observations presented herein, should be viewed as a prelude to what future holds.

\section{Acknowledgements}

This study is financially supported by the University Grants Commission, New Delhi, India. Authors are also grateful to Dr. Basudev Tripathy, Scientist of Zoological Survey of India, Kolkata for helping in identification of the species.

\section{References}

[1] Suguna VV. Food and Agriculture organization of the united nations.1989.Available from:http://www.fao.org/docrep/field/003/AB710E/AB710E12.htm.

[2] Copper, J.E, Knower, C. Snails and snail farming: an introduction for the veterinary profession, Veterinary Record, 1991; 129(21/28):541-549.

[3] Gopalakrishnan, S, Vijayavel, K. Nutritional composition of three estuarine bivalve mussels, Perna viridis, Donax cuneatus and Meretrix meretrix. Int J Food Sci Nutr,60 (6), 2009,458-463.

[4] Nagappan Nair K, Mahadevan S. Oyster culture in Tuticorin. Proc. Symp. Coastal Aquaculture Mar. Biol. Ass. India. 1983; 2: 427435.

[5] Yusufzi, S.I, Singh, H, Shirdhankar, M.M. An evaluation of different methods for transportation of the freshwater mussel Lamellidens corrianus (Lea 1834), Int. J. Aqua, 18(4),2010, 676-692.

[6] SubbaRao, N.V, Dey, A. Freshwater molluscs in Aquaculture. In: Handbook of Freshwater Molluscs of India,1989, 225-232

[7] Kambale, N.A, Potdar, V.V. Haematological analysis of Molluscan species Bellamya bengalensis and Lamiellidens marginalis, Int J Biological Forum, 1,2010,70-72.

[8] Association of Official Analytical Chemists, Official Methods of Analysis 18th Ed. Washington DC6, 1990.

[9] Association of Official Analytical Chemists, Official Methods of Analysis 17th Ed. Washington DC, 1990

[10] Somogyi, M.Notes on sugar estimation, J. Biol. Chem, 200,1952, 245

[11] Bligh, E.G, Dyer, W.J.A rapid method of total lipid extraction and purification, Canadian Journal of Biochemistry and Physiol, 37 (8), 1959,911-917.

[12] Folch, J, Lees, M, Stanley, S. GH. A simple method for the isolation and purification of total lipides from animal tissues. J. Biol. Chem, $226(1), 1957,497-509$.

[13] Chen PS, Toribara TY, Warner H. Micro-determination of phosphorus. J. Anal. Chem, 28, 1959,1756-58.

[14] Tsai, L.S, Ijichi, K, Hudson, C.A, Meehan, J.J. A method f or the quantitative estimation of cholesterol $\alpha$-oxide in Eggs, Lipids. $1980 ; 15,2: 124-128$.

[15] Litchfield, C. Analysis of triglycerides ( New York: Academic Press, 1972. )

[16] Joseph, J.D, Ackman, R.G. Capillary column gas chromatography method for analysis of encapsulated fish oil and fish oil ethyl esters: collaborative study, International Journal of AOAC,75, 1992,488-506.

[17] Baker, D.H, Han, Y. Ideal amino acid profile for chicks during the first three weeks of post hatching. J Poultry Science,73,1994,1441-1447.

[18] Sadasivam, S, Manickam, A. Biochemical Methods (New Delhi: New Age International (P) Ltd,2008) ISBN: 978-81-224-2140

[19] Omaye, S.T, Turnbull, J.D, Sauberlich, H. E. Selected methods for the determination of ascorbic acid in animal cells, tissues, and fluids. Methods Enzymol. 1979; 62:3-11.

[20] Benzie, I.F.F, Szeto, Y.T. Total antioxidant capacity of teas by the ferric reducing/ antioxidant power assay. J. Agric Food Chem,47 (2),1999,633-636.

[21] Singh, R.P, Chidambara, Murthy, K.N, Jayaprakash, G.K. Studies on antioxidant activity of pomegranate peel seed extracts using in vitro method, J. Agric. Food. Chem, 50, 2002, 86-89.

[22] Srilakshmi, B. Nutrition Science (New Delhi: New Age Publication; 2012).

[23] Emelyanov, A, Fedoseev, G, Krasnoschekova, O, Abulimity, A, Trendeleva, T, Barnes, B.P.J. Treatment of asthma with lipid extract of New Zealand green-lipped mussel: a randomized clinical trial, Eur J respire,20 (3),2002,596-600.

[24] Bender, A. Meat and meat products in human nutrition in developing countries. Food and Agriculture Organization of the United Nations (FAO), Food And Nutrition.1992; Paper 53.

[25] Chetty AN, Indira K. Alterations in the tissue lipid profiles of Lamellidens marginalis under ambient ammonia stress. Bulletin of Environmental Contamination and Toxicology, 53 (5), 1994, 693-698. 